\title{
Tinjauan Etik Prioritas Alat Pelindung Diri (APD) untuk Profesional Pemberi Asuhan (PPA) Kedokteran dan Kesehatan
}

\author{
Bachtiar Husein $^{\mathrm{I}}$, Prijo Sidipratomo ${ }^{\mathrm{I}, 2}$, Putri Dianita Ika Meilia ${ }^{\mathrm{I}, 3}$, Gilbert Mayer Christianto \\ ${ }^{\mathrm{I}}$ Majelis Kehormatan Etik Kedokteran Pengurus Besar Ikatan Dokter Indonesia \\ ${ }^{2}$ Fakultas Kedokteran Universitas Pembangunan Nasional Veteran Jakarta \\ ${ }^{3}$ Instalasi Kedokteran Forensik dan Pemulasaraan Jenazah, Rumah Sakit Umum Pusat Persahabatan, Jakarta
}

\author{
Kata Kunci \\ COVID-I9, alat pelindung diri (APD), \\ profesional pemberi asuhan (PPA), etik \\ Korespondensi \\ antalya22ftf@gmail.com \\ Publikasi \\ (C) $2020 \mathrm{JEKI} /$ ilmiah.id \\ DOI \\ I0.26880/jeki.v4i2.47
}

Tanggal masuk: I Juni 2020

Tanggal ditelaah: 25 Agustus 2020

Tanggal diterima: $3 \mathrm{I}$ Agustus 2020

Tanggal publikasi: 4 September 2020
Abstrak Sejak awal tahun 2020, COVID-I9 menjadi masalah kesehatan dunia. Di Indonesia, kasusnya pun masih terus bertambah. Seiring dengan bertambahnya jumlah kesakitan dan kematian akibat COVID-I9, seluruh komponen masyarakat, khususnya di dunia kedokteran dan kesehatan, bak sedang berperang. Dalam berperang melawan COVID-19, alat pelindung diri (APD) menjadi salah satu senjata yang penting untuk memutus rantai penularan. Terjadinya kelangkaan APD menimbulkan risiko bagi para profesional pemberi asuhan (PPA) dalam memberikan layanan kesehatan. Oleh karena itu, artikel ini akan membahas aspek etika kedokteran penggunaan APD oleh para PPA, khususnya dalam kaitannya dengan prioritas keselamatan diri agar tetap dapat memberikan layanan kesehatan yang terbaik.

Abstract Pince the beginning of 2020, COVID-ig has become a global health problem. In Indonesia, the cases are still increasing. Along with the increasing number of morbidity and deaths due to COVID-I9, all components of society, especially in the field of medicine and health, are at war. In fighting against COVID-I9, personal protective equipment (PPE) is an important weapon to break the chain of transmission. The scarcity of PPE poses a risk to health-care worker (HCW) in providing health services. Therefore, this article will discuss aspects of medical ethics in the use of PPE by HCWs, especially in relation to personal safety priorities to keep providing the best health services.

Sejak awal tahun 2020, COVID-19 menjadi masalah kesehatan dunia. Kasus ini diawali dengan informasi dari Badan Kesehatan Dunia/World Health Organization (WHO) pada tanggal 31 Desember 2019 yang menyebutkan adanya kasus kluster pneumonia dengan etiologi yang tidak jelas di Kota Wuhan, Provinsi Hubei, Cina. Pada tanggal 7 Januari 2020, Cina mengidentifikasi etiologinya sebagai jenis baru (novel) coronavirus yang dinamakan Sars-CoV-2 (Severe Akut Respiratory syndromeCoV2). ${ }^{1}$ Pada tanggal 12 Februari 2020, WHO resmi menetapkan penyakit novel coronavirus pada manusia ini dengan sebutan Coronavirus Disease 2019 (COVID- 19).

Kasus ini terus berkembang hingga adanya laporan kematian dan terjadi eksportasi ke luar Cina. Pada tanggal 30 Januari 2020, WHO menetapkan COVID-19 sebagai Public Health
Emergency of International Concern (PHEIC)/ Kedaruratan Kesehatan Masyarakat Yang Meresahkan Dunia (KKMMD). Penambahan jumlah kasus COVID-19 berlangsung cukup cepat dan sudah terjadi penyebaran antar negara sehingga pada tanggal 11 Maret 2020, WHO menetapkan COVID-19 sebagai pandemi. Di Indonesia, kasus terkonfirmasi COVID-19 pertama kali dilaporkan pada tanggal 2 Maret 2020. Infeksi Novel Coronavirus sudah ditetapkan sebagai penyakit yang dapat menimbulkan wabah sesuai Kepmenkes Nomor: HK.01.07/MENKES/104/20201.

Dalam berperang melawan wabah ini, kita memerlukan strategi yang baik, termasuk strategi memutus rantai penularan dengan menggunakan alat pelindung diri (APD) yang sesuai. Agar kita berhasil dalam berperang melawan COVID-19, penggunaan APD yang 
tepat menjadi krusial, terutama bagi para profesional pemberi asuhan (PPA) kesehatan. Namun, apa yang harus dilakukan jika terjadi kelangkaan APD sedangkan layanan kesehatan harus tetap berjalan? Dalam artikel ini akan didiskusikan aspek etika kedokteran penggunaan APD oleh para PPA, khususnya dalam kaitannya dengan prioritas keselamatan diri.

\section{Kejadian Luar Biasa, Wabah, dan Upaya Penanggulangan}

Kejadian Luar Biasa (KLB) adalah timbulnya atau meningkatnya kejadian kesakitan dan/atau kematian yang bermakna secara epidemiologi pada suatu daerah dalam kurun waktu tertentu, dan merupakan keadaan yang dapat menjurus pada terjadinya wabah. ${ }^{2}$

Penetapan suatu daerah dalam keadaan wabahdilakukanapabilasituasiKLBberkembang atau meningkat dan berpotensi menimbulkan malapetaka, dengan pertimbangan sebagai berikut:

a. Secara epidemiologis data penyakit menunjukkan peningkatan angka kesakitan dan/atau angka kematian.

b. Terganggunya keadaan masyarakat berdasarkan aspek sosial budaya, ekonomi, dan pertimbangan keamanan.

Kementerian Kesehatan Republik Indonesia telah menentukan bahwa bila ditemukan satu kasus konfirmasi COVID-19 di suatu daerah maka di daerah tersebut dinyatakan terjadi KLB. ${ }^{1}$

COVID-19 menular dari manusia ke manusia melalui percikan batuk/bersin (droplet). Orang yang paling berisiko tertular penyakit ini adalah orang yang kontak erat dengan pasien COVID-19, yaitu mereka yang melakukan kontak fisik atau berada dalam ruangan atau berada dalam radius 1 - 2 meter dengan pasien COVID-19. Gejala bisa muncul dalam 2 hingga 14 hari setelah terinfeksi. Para profesional pemberi asuhan (PPA), termasuk dokter, perawat, petugas farmasi, petugas laboratorium, sampai ke petugas kebersihan, yang memeriksa, merawat, mengantar, dan membersihkan ruangan di tempat perawatan pasien termasuk kelompok paling berisiko untuk tertular penyakit ini.

Sesuai UU no 4 th 1984 Pasal 5 upaya penanggulangan wabah mempunyai dua tujuan pokok yaitu:

1. Berusaha memperkecil angka kematian akibat wabah dengan pengobatan.

2. Membatasi penularan dan penyebaran penyakit agar penderita tidak bertambah banyak, dan wabah tidak meluas ke daerah lain.

Upaya penanggulangan wabah meliputi:

1. penyelidikan epidemiologis,

2. pemeriksaan, pengobatan, perawatan, dan isolasi penderita, termasuk tindakan karantina,

3. pencegahan dan pengebalan,

4. pemusnahan penyebab penyakit,

5. penanganan jenazah akibat wabah,

6. penyuluhan kepada masyarakat,

7. upaya penanggulangan lainnya.

Pencegahan dan pengebalan adalah tindakan-tindakan yang dilakukan untuk memberi perlindungan kepada orang-orang yang belum sakit, akan tetapi mempunyai risiko untuk terkena penyakit. Rekomendasi standar untuk mencegah penyebaran infeksi adalah melalui cuci tangan secara teratur menggunakan sabun dan air bersih, menerapkan etika batuk dan bersin, menghindari kontak dekat dengan orang sakit ataupun yang menunjukkan gejala penyakit terutama untuk penyakit pernapasan yang sangat menular. Selain rekomendasi standar, untuk pasien COVID-19 dan kelompok berisiko perlu melakukan langkah untuk mencegah penularan virus Sars-CoV-2 berupa isolasi diri dan/atau karantina, serta penggunaan alat pelindung diri (APD) yang sesuai. Bagi fasilitas layanan kesehatan penerapan Program Pencegahan dan Pengendalian Infeksi (PPI) merupakan hal yang menjadi semakin penting saat ini. ${ }^{1}$

\section{Alat Pelindung Diri}

Alat Pelindung Diri (APD) adalah kelengkapan yang wajib digunakan saat bekerja sesuai bahaya dan risiko kerja untuk menjaga keselamatan pekerja itu sendiri dan orang di sekelilingnya. Dalam kasus wabah penyakit menular, alat pelindung diri adalah kesiapan 
logistik yang krusial, layaknya obat-obat suportif (lifesaving), alat-alat kesehatan dan penunjang kesehatan lainnya. Bagi petugas kesehatan, penggunaan alat pelindung diri dibutuhkan untuk proteksi diri agar tenaga kesehatan tidak terjangkit penyakit. Hal ini patut diperhatikan karena selain kewajiban terhadap pasien, tenaga kesehatan memiliki tanggung jawab untuk menjaga kesehatan diri sendiri. ${ }^{3}$

Dalam penjelasan dan pedoman pelaksanaan Kode Etik Kedokteran Indonesia (KODEKI) Pasal 16 disebutkan bahwa setiap dokter harus memelihara kesehatannya, termasuk melaksanakan tindakan perlindungan diri. Jika ada wabah maka PPA harus mengambil tindakan untuk melindungi dirinya terlebih dahulu sebelum menolong orang lain. Contohnya, PPA harus menjadi teladan dalam melaksanakan protokol kesehatan, penggunaan APD, dan kelak apabila sudah tersedia imunisasi, maka PPA perlu diprioitaskan untuk mendapatkan imunisasi terlebih dahulu. Tindakan perlindungan diri ini dilakukan supaya dokter dapat tetap melakukan perawatan pasien dengan baik. ${ }^{3}$ Sebagai analogi, kita dapat mengambil protokol keselamatan saat naik pesawat: Jika terjadi penurunan tekanan udara secara tiba-tiba, maka kita sendiri wajib mengenakan masker oksigen terlebih dahulu sebelum menolong orang lain. Siapa yang akan melakukan pengobatan dan perawatan terhadap pasien apabila PPA sakit?

Dari sisi ketentuan hukum, penyediaan APD ini menjadi tanggung jawab fasilitas layanan kesehatan untuk mempersiapkan sumber daya dan logistik agar para pekerjanya dapat menjalankan tugas dengan baik. Bila pihak penyedia layanan kesehatan tidak menyediakan alat pelindung diri, maka dari sisi hukum sebenarnya dapat diberikan sanksi administratif dari dinas kesehatan ditempat fasilitas kesehatan tersebut bernaung (Pasal 12 PMK no 52 tahun 2018). Di sisi lain, merujuk pada UU no 36 tahun 2014 pasal 4 tercermin tanggung jawab pemerintah terhadap tenaga kesehatan, yaitu:

a. pengaturan, pembinaan, pengawasan, dan peningkatan mutu Tenaga Kesehatan,

b. perencanaan, pengadaan, dan pendayagunaan Tenaga Kesehatan sesuai dengan kebutuhan,

c. pelindungan kepada Tenaga Kesehatan dalam menjalankan praktik.

Alat pelindung diri wajib tersedia untuk petugas kesehatan dalam menjalankan perawatan pasien COVID-19. Memperoleh perlindungan atas keselamatan dan kesehatan kerja adalah hak tenaga kesehatan. Pernyataan ini dilindungi hukum sesuai yang tertulis dalam pasal 57 UU no 36 tahun 2014 tentang tenaga kesehatan. ${ }^{4}$ Selain untuk proteksi diri, penggunaan APD yang sesuai untuk mencegah transmisi agen infeksius dari pasien ke orang lain.

WHO dan kementerian kesehatan sudah mengeluarkan pedoman mengenai penggunaan alat pelindung diri yang benar sesuai dengan faktor risiko, baik bagi para profesional kesahatan dan juga bagi khalayak awam. APD yang direkomendasikan oleh WHO dan Kementerian Kesehatan Republik Indonesia bagi petugas kesehatan saat menangani pasien COVID-19 harus menggunakan APD level 3 antara lain pelindung mata atau, pelindung wajah, penutup kepala, masker N95 atau yang setingkat, sarung tangan, gown all-cover atau apron, sarung tangan double sterile, dan sepatu boot. ${ }^{1}$

Namun dapat difahami, pada kondisi pandemi wabah di seluruh dunia seperti yang terjadi sekarang ini dapat terjadi ketimpangan antara jumlah APD yang dibutuhkan dengan jumlah sumber daya yang tersedia, menyebabkan timbulnya kelangkaan APD. Kelangkaan APD ini lebih disebabkan oleh lonjakan drastis kebutuhan APD yang terjadi karena tenaga medis bekerja serentak melayani ribuan pasien, sedangkan di sisi lain pasokan APD belum dapat dipenuhi oleh produsen.

Pada situasi kelangkaan APD, diperlukan sebuah tindakan untuk menjaga agar para tenaga kesehatan tetap memiliki alat dan bahan yang dibutuhkan dalam upaya penanganan COVID-19. Tindakan tersebut di antaranya adalah gotong royong antara seluruh komponen masyarakat, produsen, pemilik alat-alat produksi yang menunjang produksi APD, serta pemerintah untuk bahu membahu 
mengupayakan penyediaan APD dengan jumlah yang memadai. Di sisi lain, dapat dilakukan perampingan/konsentrasi tempat pelayanan kesehatan dengan penjadwalan aktivitas tenaga medis dan tenaga kesehatan, atau penjadwalan buka tutup hari pelayanan RS untuk menekan laju kebutuhan terhadap APD.

Bagi masyarakat, pemakaian APD perlu disesuaikan dengan kondisi dan risiko masingmasing individu. WHO merekomendasikan penggunaan APD berupa masker bedah bagi pasien COVID-19 atau suspek pasien COVID-19 dan bagi keluarga yang merawat pasien atau kontak erat lainnya. Untuk masyarakat yang sehat, dan tidak ada kontak erat dengan pasien COVID-19, tindakan pencegahan cukup dilakukan dengan menerapkan hand-hygiene, menggunakan masker kain berlapis, dan physical distancing, disertai edukasi terkait etika batuk/ bersin. ${ }^{1}$

Namun, sayangnya masih ada kalangan masyarakat yang belum mengetahui mengenai standar pencegahan infeksi ini. Disisi lain, muncul berbagai berita yang tidak benar (hoax) yang malah membuat masyarakat menjadi "hyperaware", dengan kata lain menjadi cemas sampai paranoid, dan membeli bahkan menimbun alat pelindung diri yang diperuntukkan untuk tenaga kesehatan. Disaat seperti ini komunikasi informasi dan edukasi (KIE) berperan penting. Baik pihak pemerintah, professional, dan juga masyarakat perlu turut berpartisipasi untuk terus mengawal berita dan informasi yang beredar di masyarakat.

Sementara itu, ada juga pihak-pihak yang justru mengambil keuntungan atas penderitaan orang lain. Terdapat laporan bahwa ada oknum yang memborong APD dan menjual kembali alat-alat tersebut dengan harga yang jauh lebih mahal. Tindakan ini tentu menggangu upaya penanggulangan wabah dan membahayakan tenaga kesehatan sebagai lini pertama penanganan COVID-19. Tindakan yang menimbulkan gangguan upaya penanggulangan wabah dapat dikenakan UU no 4 tahun 1984 Pasal 14 yang berbunyi:

“(1) Barang siapa dengan sengaja menghalangi pelaksanaan penanggulangan wabah sebagaimana diatur dalam Undang-Undang ini, diancam dengan pidana penjara selama-lamanya 1 (satu) tahun dan/ atau denda setinggi-tingginya Rp 1.000.000,- (satu juta rupiah)."

Menurut pasal tersebut, tindak pidana yang menghalangi proses penanggulangan wabah merupakan kejahatan dan dapat dikenakan denda bahkan dipenjara. ${ }^{2}$

Penanggulangan wabah penyakit menular bukan hanya semata menjadi wewenang dan tanggung jawab Kementerian Kesehatan, tetapi menjadi tanggung jawab bersama. Oleh karena itu dalam pelaksanaan penanggulangannya memerlukan keterkaitan dan kerjasama dari berbagai lintas sektor pemerintah dan masyarakat. Dalam hal penyediaan logistik, pemerintah akan kewalahan sendiri apabila tidak melibatkan partisipasi masyarakat. Pemerintah perlu menjalin kerjasama dengan berbagai sektor untuk menyediakan sumber daya yang dibutuhkan. Pemerintah segera mengadakan APD dari berbagai sumber, baik impor maupun menggerakkan produksi APD dengan melibatkan perusahaan tekstil di berbagai daerah, termasuk Usaha Menengah Kecil Masyarakat (UMKM), dengan standar teknis sesuai persyaratan WHO. Keterkaitan berbagai sektor dalam upaya penanggulangan wabah tersebut sesuai dengan tugas, wewenang dan tanggung jawabnya dalam upaya penanggulangan wabah. Dengan keterkaitan berbagai sektor, pemerintah perlu bertindak untuk mengoordinasikan dan menjaga agar usaha-usaha penyediaan APD dan keperluan lainnya bisa terlaksana dengan baik dan benar. Perlunya data yang akurat mengenai jumlah APD yang tersedia di lapangan dan jumlah APD yang dibutuhkan agar bisa dilakukan distribusi efektif bagi seluruh fasilitas kesehatan yang terlibat dalam penanganan COVID-19.

\section{KESIMPULAN}

Dalam upaya penanggulangan wabah penyakit menular, harus dilakukan secara terpadu dengan upaya kesehatan lain, yaitu upaya pencegahan, penyembuhan dan pemulihan kesehatan. Pengendalian administratif merupakan prioritas pertama dari strategi Pencegahan dan Pengendalian Infeksi 
(PPI) termasuk penyediaan infrastruktur, kebijakan dan prosedur dalam mencegah, mendeteksi, dan mengendalikan infeksi selama perawatan kesehatan.

Beberapa hal yang perlu diperhatikan dalam penanganan wabah COVID-19:

1. Pengadaan dan Produksi Darurat Alat Pelindung Diri (APD). Pemerintah segera mengadakan APD dari berbagai sumber, baik impor maupun menggerakkan produksi APD dalam negeri, dengan standar teknis dan sesuai persyaratan WHO. Pemerintah perlu melibatkan pihak swasta, ahli tekstil, ahli kesehatan, organisasi kesehatan yang relevan untuk mendorong terwujudnya pengadaan dan produksi APD yang sangat urgen.

2. Distribusi yang efektif: pemerintah segera mendistribusikan APD ke semua rumah sakit yang terlibat dalam respon terhadap COVID-19, sekaligus mengambil tindakan tegas bagi pelaku penjualan APD dengan harga yang tidak wajar.

3. Pendampingan Komunikasi, Informasi dan Edukasi yang benar untuk mencegah berita hoax dan untuk meyakinkan masyarakat agar tidak timbul kepanikan massal.

\section{KONFLIK KEPENTINGAN}

Tidak ada konflik kepentingan.

\section{REFERENSI}

1. Kemenkes RI. Pedoman Pencegahan dan Pengendalian Coronavirus Disease (COVID-19). Edisi 27 Maret 2020.

2. Undang-undang RI. Wabah Penyakit Menular. UU RI no 4 tahun 1984.

3. Kode Etik Kedokteran Indonesia

4. Undang-undang RI. Tenaga Kesehatan. UU RI no 36 tahun 2014.

5. Permenkes RI. Keselamatan dan Kesehatan kerja di fasilitas layanan kesehatan. Permenkes no 52 tahun 2018. 